\title{
Historical perspectives of The American Association for Thoracic Surgery: Julian Johnson (1906-1987)
}

\section{J. William Gaynor, MD}

Julian Johnson, the 43rd president of The American Association for Thoracic Surgery (AATS), reminisced about his career and his introduction to thoracic surgery in his presidential address entitled "A surgeon and something more" on April 9, 1963. ${ }^{1}$ He noted that, during his surgical training in the early 1930s, the prestige and reputation of the field of thoracic surgery were not uniformly high. While a surgical resident in Philadelphia, he heard a local thoracic surgeon state that he did not want to be known as a thoracic surgeon because he did not think he could earn a living in thoracic surgery alone. Johnson also noted that during the developmental stage of thoracic surgery, it was inevitable that the early members of the association were general surgeons who had taken an interest in thoracic surgery hoping to develop the field further.

Johnson initially trained as a general surgeon; his formal training in thoracic surgery consisted of a 2-month rotation as an intern with George P. Muller, 15th AATS president, and a 2-week visit to Boston to observe Edward D. Churchill, 28th AATS president, and Richard H. Overhault. ${ }^{1,2}$ Dr Muller's interests in thoracic surgery were primarily empyema and lung abscess. In Boston, Johnson observed both the multiple- and single-ligature methods for pneumonectomy, and on return to Philadelphia, he began to use the single-ligature technique. He had only 1 death in his first 30 pneumonectomies, a lower mortality rate than any reported in the country at that time. Johnson considered himself a general surgeon who also performed thoracic surgery and characterized himself as one of the last members of the AATS who might be called a "do-it-yourself" thoracic surgeon. "In short then, of all the operations now being performed in modern thoracic and cardiovascular surgery, I had witnessed only three aside from those mentioned before doing the operation myself.",

Johnson was born in Kentucky on July 3, 1906. At 21 years of age, after graduating from Maryville College, he entered the University of Pennsylvania School of Medicine. He was elected to Alpha Omega Alpha and graduated in 1931, after which he accepted a surgical internship at

\footnotetext{
From the Division of Cardiothoracic Surgery, Children's Hospital of Philadelphia, Philadelphia, Pa.

Received for publication Feb 14, 2011; accepted for publication March 21, 2011.

Address for reprints: J. William Gaynor, MD, Division of Cardiothoracic Surgery,

Children's Hospital of Philadelphia, 34th and Civic Center Blvd, Philadelphia,

PA 19104 (E-mail: gaynor@email.chop.edu).

J Thorac Cardiovasc Surg 2011;142:493-5

$0022-5223 / \$ 36.00$

Copyright (C) 2011 by The American Association for Thoracic Surgery

doi:10.1016/j.jtcvs.2011.03.021
}

the Hospital of the University of Pennsylvania., ${ }^{2,3}$ Dr I. S. Ravdin had been appointed the first J. William White Professor of Surgical Research at the University of Pennsylvania in 1928. Dr Ravdin subsequently secured a $\$ 2,400,000$ bequest from George Leib Harrison. The Department of Surgery was renamed in honor of Mr Harrison, and the funds were used, in part, to support a formal surgical research program. The initial group of Harrison Research Fellows included Jonathon E. Rhoads (renowned general surgeon), Julian Johnson, and John H. Gibbon, 40th AATS president; Johnson's research involved a detailed study of biliary tract physiology. In 1939, he completed his training and accepted a faculty position at the University of Pennsylvania. He was assigned by his chief, Eldridge L. Eliason, to develop thoracic surgery at the hospital; however, the entry of the United States into the Second World War brought new challenges.

In the Pacific Theater Johnson served in the 20th General Hospital, which had been organized from the Hospital of the University of Pennsylvania by Drs I. S. Ravdin and Thomas Fitzhugh. ${ }^{4}$ The 20th General Hospital saw service during the campaign near North Burma at the western base of the Burma Road to China (Figure 1). During his years of military service, Johnson was particularly interested in battle wounds of the thoracic cavity. In an article published in 1946, he reviewed the management of more than 300 patients with trauma to the thoracic cavity treated from 1943 to $1945 .^{5}$ The majority of the wounds were due to small-arms fire or shrapnel from mines, bombs, and grenades. Despite the difficulties of jungle warfare, the primitive surgical facilities, and frequent associated injuries, the overall mortality was only $7.4 \%$. Many of the management strategies described remain relevant today. In the conclusion of this article, Johnson noted that once a patient with a wound of the thoracic cavity was over the immediate threat to life, the chief objective in treatment should be complete restoration of function. He concluded that the most important factor in the restoration of function was early re-expansion of the lung in patients with hemopneumothorax by means of early drainage. He advocated early thoracotomy for evacuation of the clot when drainage was not successful.

After the war, Johnson returned to Philadelphia, eventually serving as the chief of cardiothoracic surgery until his retirement in 1973. His initial clinical focus included pulmonary, esophageal, and thyroid surgery. Early in his career, Johnson became interested in cardiac resuscitation. In 1941, he designed and built a defibrillator and reported 


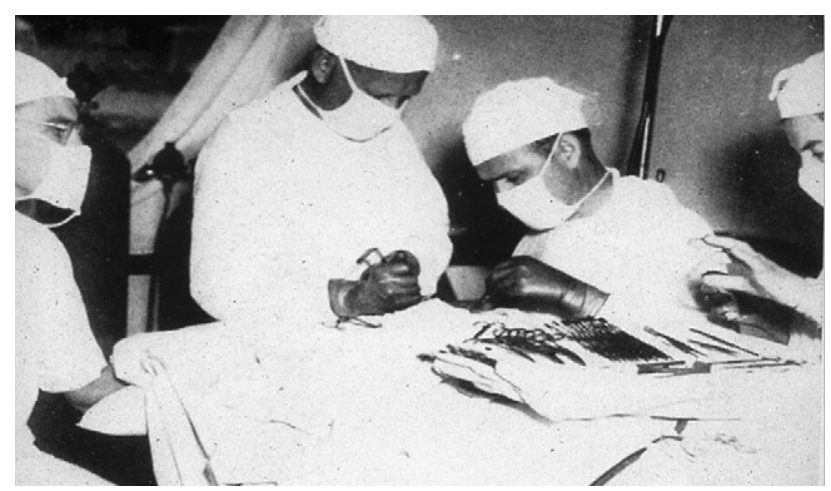

FIGURE 1. Major Julian Johnson operating at the 20th General Hospital in the China/Burma/India Theater (courtesy of the Trustees of the University of Pennsylvania).

4 successful resuscitations from ventricular fibrillation in $1951 .{ }^{6,7}$ His practice expanded to include closed valvular procedures, and he developed an interest in congenital heart surgery and began the congenital heart surgery program at the Children's Hospital of Philadelphia. After the first successful use of cardiopulmonary bypass by John Gibbon, Johnson initiated the open heart surgery programs at the University of Pennsylvania and Children's Hospital. By 1964, he and his associates (including Charles Kirby and Gordon Danielson) were able to report a combined series from the 2 institutions of 100 consecutive open heart surgeries using the Mayo-Gibbon pump, with a mortality of $10 \% .^{8}$

Johnson was particularly interested in the training of future thoracic and cardiac surgeons. He served on the American Board of Thoracic Surgery from 1952 to 1957. Many of the issues he considered important remain controversial and are still being debated in the current era. The appropriate training of future thoracic surgeons was the primary topic of his presidential address. ${ }^{1}$ He considered himself fortunate to have been trained as a general surgeon and to have grown up with the field of thoracic surgery during his early years. He was emphatic in his belief that thoracic surgeons should be general surgeons first:

In the early days of the Board of Thoracic Surgery there was considerable disagreement with the established policy of requiring that the surgeon pass the American Board of Surgery before being given an opportunity to take the examination of the Thoracic Board. Those of us who were taken into the founding group did not all see eye to eye regarding this problem. It was the opinion of some that it was an undue hardship for the young man who expected to go into thoracic surgery alone to make him go through a long and arduous surgical training period. During the five year period that I served on the Board of Thoracic Surgery, I along with the other members stoutly defended the view that a man should be well grounded in general surgery and should be required to pass the American Board of Surgery before taking the Thoracic Boards. I am glad to say that this policy has been sustained until this time and I am hopeful that the efforts to persuade the Board to do otherwise have ceased....

Johnson worried about the content and quality of thoracic surgical training. He was concerned about what he termed "a great tendency on a ward service in an academic institution for a surgical resident to become a clerk who operates." He thought that shortening the training process would have an adverse effect on thoracic surgery and was opposed to any "alteration of our training program in such a way as to narrow the base, and in an effort to short cut fundamentals, the development of a technician who is not well founded in surgical principles." He worried that no longer requiring thoracic surgeons to be general surgeons would lead to fragmentation and marginalization of the field: "I would hate to find the thoracic or even the cardiac surgeons of this country set aside as an entirely separate and autonomous group in a fashion to that of other surgical specialties in which the individuals who operate are not conceded by most of us to be surgeons in the broad sense of the term." It seems unlikely that Dr Johnson would approve of either the increasing subspecialization of cardiothoracic surgery or the new cardiothoracic surgery residency and fellowship programs. As he concluded his presidential address, Johnson stated

Dr Gross, my hope as president of The American Association for Thoracic Surgery is that this Association may continue to exert its influence in bringing about general acceptance of the importance of a broad medical background and thorough training in fundamental surgical principles in the making of a thoracic surgeon. Indeed may we strive to be able to say with justifiable pride that a thoracic surgeon is 'a surgeon and something more.'

As president of the Association, Dr Johnson remained optimistic, with a positive vision of the future of cardiothoracic surgery. In his presidential address he reviewed the tremendous progress during his career and predicted major advances in thoracic oncology and treatment of the failing heart. $^{1}$

In the twenty-five years that have passed since I visited Boston in 1938, thoracic surgery, which includes cardiac surgery, has advanced at such a rapid pace that the life of a thoracic surgeon has been one of almost constant adventure. I have counted myself fortunate to have lived in this period. I will not make the mistake of saying that 'we have gone about as far as we can go.' I have every reason to hope that the advances 

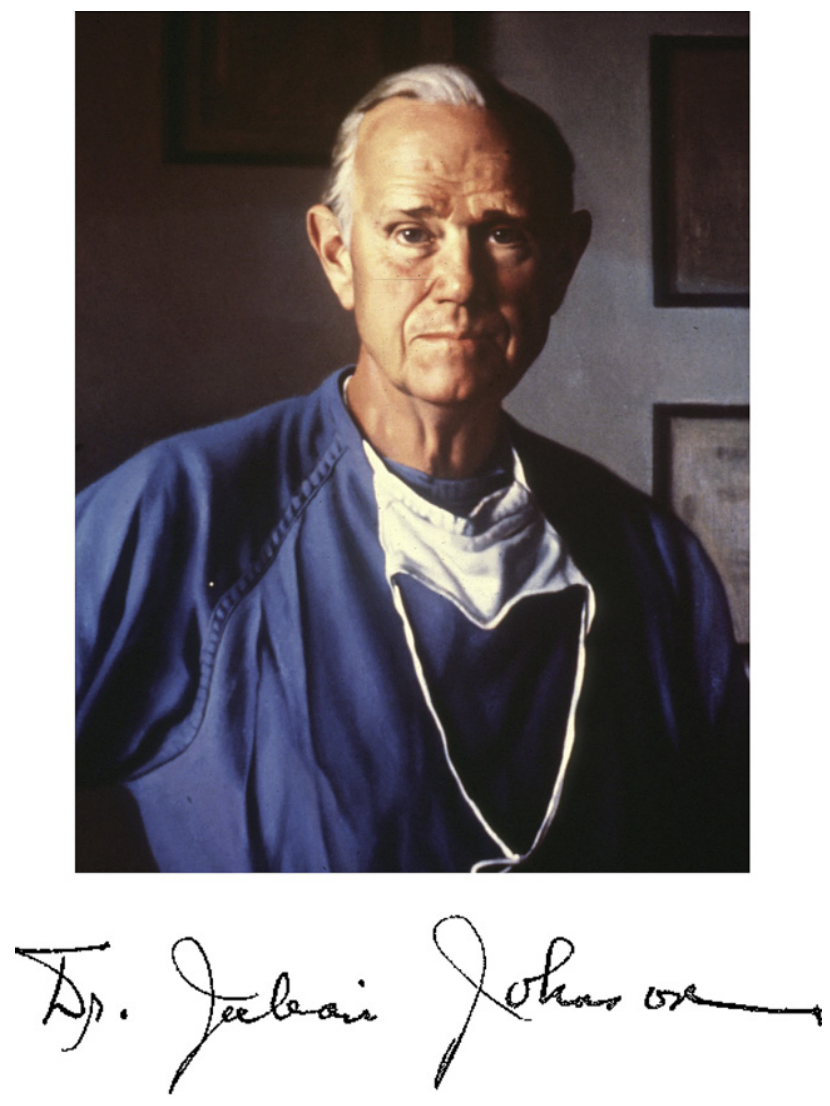

FIGURE 2. Portrait of Julian Johnson in the Harrison Department of Surgery at the Hospital of the University of Pennsylvania (courtesy of the Trustees of the University of Pennsylvania).

of the next twenty-five years will far outdistance those of the last twenty-five. It is difficult for me to believe, for example, that the mysteries of the cancer cell can evade us for another twenty-five years. Also I certainly hope to live to see the end of the race between the groups hoping to replace the failing human heart-one by means of an artificial mechanical device, the other by a homo- or heterotransplant. At the University of Pennsylvania we are placing our money on the mechanical device.

Almost 50 years later, despite his optimism, full achievement of these goals remains elusive.

Julian Johnson died in 1987, but his legacy lives on at the University of Pennsylvania. After his retirement in 1973, a portrait of Dr Johnson in a surgical gown was placed in the Harrison Department of Surgery (Figure 2). An endowed chair was created in his honor, and L. Henry Edmunds serves as the current Julian Johnson Professor of Cardiac Surgery. A self-taught thoracic surgeon, Julian Johnson was a pioneer and one of the founders and shapers of modern cardiothoracic surgery. He was proud of his chosen profession, optimistic about its future, and firm in his belief that "a thoracic surgeon is a surgeon and something more."

\section{References}

1. Johnson J. A surgeon and something more. J Thorac Cardiovasc Surg. 1963;46: 141-9.

2. Edmunds LH. In memoriam: Julian Johnson (1906-1987). J Thorac Cardiovasc Surg. 1988;96:515-7.

3. Rhoads JE. Julian johnson 1906-1987. Trans Stud Coll Physicians Philadelphia. 1987;9:300-3.

4. North JP. The 20th general hospital-I.S. Ravdin, commanding general. Surgery. 1964;56:614-23.

5. Johnson J. Battle wounds of the thoracic cavity. Ann Surg. 1946;123:321-42.

6. Johnson J. Cardiac standstill and ventricular fibrillation. Am Pract Digest Treat. 1954;5:264.

7. Johnson J. The treatment of cardiac arrest. Postgrad Med. 1955;18:553-7.

8. Johnson J. An analysis of 100 consecutive operations utilizing the Mayo-Gibbon heart lung machine. Surgery. 1964;56:711-8. 